\title{
Subgrouping School-Aged Children with Autism Spectrum Disorder Based on Co-Occurring Psychopathology
}

aDepartment of Psychiatry and Behavior Sciences, Weill Institute for Neurosciences, University of California, San Francisco, 401 Parnassus Ave, San Francisco, CA, 94143, USA;

antonia.piergies@ucsf.edu (A. M. H. P.); tomoya.hirota@ucsf.edu (T. H.); shuting.zheng@ucsf.edu (S. Z.)

bepartment of Biomedical Statistics, Graduate School of Medicine, Osaka University, 2-2;

Yamadaoka, Suita, Osaka, 565-0871, Japan; monden@biostat.med.osaka-u.ac.jp (R. M.)

'University of Groningen, University Medical Center Groningen, Interdisciplinary Center Psychopathology and Emotion Regulation (ICPE), Hanzeplein 1, 9713 GZ Groningen, Netherlands

${ }^{\dagger}$ Corresponding author 
medRxiv preprint doi: https://doi.org/10.1101/2021.07.19.21260784; this version posted December 1, 2021. The copyright holder for this preprint (which was not certified by peer review) is the author/funder, who has granted medRxiv a license to display the preprint in perpetuity.

It is made available under a CC-BY-NC-ND 4.0 International license .

SUBGROUPING BASED ON CO-OCCURRING PSYCHOPATHOLOGY

\begin{abstract}
Background: Phenotypic heterogeneity within autism spectrum disorder (ASD) is compounded by cooccurring psychopathology. Deriving subgroups of individuals with ASD based on co-occurring psychopathology could better our understanding of symptom patterns existing within this population. This study's goals were to derive subgroups of school-aged children with ASD based on co-occurring psychopathology while controlling for age and sex and to examine correlates of subgroup membership while controlling for ASD symptom severity. Method: Latent class models were estimated with a sample from the Simons Simplex Collection $(n=2,087)$ using borderline/clinical versus normal range data from five of the DSM-Oriented Scales of the Child Behavior Checklist for Ages 6 to 18 as indicator variables. We evaluated the predictive value of nonverbal IQ $(N V I Q)<70$, sleep disturbance, allergies/autoimmune disorders, gastrointestinal disorders, and neurological disorders on subgroup membership using multinomial logistic regression. Results: Four subgroups emerged: "Low Psychopathology" (41.02\%), "Externalizing Problems" (12.36\%), "Internalizing Problems" (31.58\%), and "High Psychopathology" (15.05\%). The most significant findings were that $\mathrm{NVIQ}<70$ was associated with decreased odds of belonging to the "Internalizing Problems" and "High Psychopathology" subgroups over the "Low Psychopathology" subgroup, while sleep disturbance and gastrointestinal disorders were associated with increased odds of belonging to the "Externalizing Problems" and "High Psychopathology" subgroups. Neurological disorders was also associated with increased odds of belonging to the "Externalizing Problems" subgroup. Conclusion: Patterns of psychopathology exist within school-aged children with ASD and are correlated with $\mathrm{NVIQ}<70$, sleep disturbance, as well as medical conditions, providing guidance for clinical practice and etiology-driven research.
\end{abstract}

Keywords: autism spectrum disorder, latent class analysis, co-occurring psychopathology, nonverbal $\mathrm{IQ}$, sleep disturbance, medical conditions 
medRxiv preprint doi: https://doi.org/10.1101/2021.07.19.21260784; this version posted December 1, 2021. The copyright holder for this preprint (which was not certified by peer review) is the author/funder, who has granted medRxiv a license to display the preprint in perpetuity. It is made available under a CC-BY-NC-ND 4.0 International license .

SUBGROUPING BASED ON CO-OCCURRING PSYCHOPATHOLOGY

\section{Introduction}

Co-occurring psychopathology is prevalent among children with autism spectrum disorder (ASD; Rosen et al., 2018), with 70-91\% meeting diagnostic criteria for at least one psychiatric disorder at some point during their lifetimes (Leyfer et al., 2006; Simonoff et al., 2008; Salazar et al., 2015; Mosner et al., 2019). Common co-occurring psychiatric disorders include anxiety disorders, attention-deficit/hyperactivity disorder (ADHD), depressive disorders, obsessive-compulsive disorder (OCD), and oppositional defiant disorder (ODD; Simonoff et al., 2008; Gjevik et al., 2011; Lai et al., 2019).

The presence of psychiatric disorders has been linked to increased impairments in adaptive, social, and academic functioning (Kim et al., 2000; Sikora et al., 2012; Kaat et al., 2013), and can make diagnosing ASD and treating related symptoms more challenging (Levy et al., 2010; Rosen et al., 2018). For example, the presence of internalizing and externalizing problems-those that are internally- (e.g., anxiety problems) and externally-driven (e.g., conduct problems), respectively—has been shown to impact the sensitivity and specificity of commonly-used ASD symptom measures, including the Autism Diagnostic Interview-Revised (ADI-R), the Autism Diagnostic Observation Schedule (ADOS), the Modified Checklist for Autism in Toddlers (MCHAT), and the Social Responsiveness Scale (SRS; Havdahl et al., 2016; Colombi et al., 2019; Christopher et al., 2020). Additionally, the presence of internalizing and externalizing problems appears to affect treatment outcomes. For example, in one study, children with ASD and ADHD reportedly did not respond to a ten-week social skills training, whereas those with ASD and an anxiety disorder or ASD alone did (Antshel et al., 2011).

Co-occurring psychopathology further contributes to the phenotypic heterogeneity of ASD. On the one hand, co-occurring psychopathology can exacerbate core ASD symptoms (Wood \& Gadow, 2010; Sprenger et al., 2013) and symptoms associated with other disorders (Sinzig et al., 2008). For example, compared to children with ASD or ADHD alone, children with co-occurring ASD and ADHD present with greater attention and social deficits (Sinzig et al., 2008; Sprenger et al., 2013), and those with an anxiety or a depressive disorder present with more restricted/repetitive behaviors and social withdrawal (Chandrasekhar \& Sikich, 2015; Muskett et al., 2019). On the other hand, co-occurring psychopathology can make associated symptoms, such as anxiety, present atypically (Kerns \& Kendall, 2012). Given that some psychiatric disorders are more likely to present together in the same child than others-for 
medRxiv preprint doi: https://doi.org/10.1101/2021.07.19.21260784; this version posted December 1, 2021. The copyright holder for this preprint (which was not certified by peer review) is the author/funder, who has granted medRxiv a license to display the preprint in perpetuity. It is made available under a CC-BY-NC-ND 4.0 International license .

SUBGROUPING BASED ON CO-OCCURRING PSYCHOPATHOLOGY

example, an ADHD diagnosis is often accompanied by diagnoses of an anxiety disorder, a mood disorder, or ODD (Gadow et al., 2008a; Gordon-Lipkin et al., 2018)—patterns of psychopathology are suspected to exist in this population. Deriving subgroups based on co-occurring psychopathology could facilitate the identification of symptom patterns in this population, which could in turn be used in future studies to better our understanding of the shared and distinct mechanisms underlying specific psychopathology profiles. Transdiagnostic constructs, in particular, could prove useful to prevention, screening, detection, and intervention efforts and lead to more efficient delivery of services. For example, shifting the focus of psychiatric symptom measures away from diagnostic categories and towards constructs that are impaired across disorders would allow for treatments that are both more tailored to one's needs and more generalizable along the autism spectrum, as children with ASD often present with multiple co-occurring psychiatric disorders (Simonoff et al., 2008).

One useful technique for deriving subgroups is latent class analysis (LCA; Porcu \& Giambona, 2017), a person-centered approach that assigns individuals to otherwise unobserved classes based on a combination of observed categorical variables. Several studies have used person-centered approaches when attempting to disentangle the heterogeneity in the presentation of ASD's core symptoms (Gotham et al., 2012; Lord et al., 2012; James et al., 2016; Lerner et al., 2017; Kim et al., 2019; Harris et al., 2021) and other developmental and behavioral characteristics (Landa et al., 2012; Wiggins et al., 2017; Kang et al., 2020; Zheng et al., 2020). However, relatively little attention in the subgrouping literature has been given to co-occurring psychopathology, which has been recognized as an area of high importance to the autism community (Lombardo et al., 2019). The few studies that have considered co-occurring psychopathology when subgrouping children with ASD are limited in that they either focused on older, school-aged children ( $\geq 15$ years) and aggregated all psychiatric symptoms into a single, large category (Doshi-Velez et al., 2014) or focused on younger, preschool-aged children and kept psychiatric symptoms separated (Wiggins et al., 2017; Nordahl et al., 2020). Additionally, all these studies included other childlevel indicator variables (e.g., adaptive functioning, cognitive development) in their models along with psychopathology. Although these studies have demonstrated the potential for identifying more homogeneous ASD subgroups, no study has systematically examined whether meaningful subgroups of children within the entire school-aged range (six to 18 years) - a period in which most psychiatric 
medRxiv preprint doi: https://doi.org/10.1101/2021.07.19.21260784; this version posted December 1, 2021. The copyright holder for this preprint (which was not certified by peer review) is the author/funder, who has granted medRxiv a license to display the preprint in perpetuity.

It is made available under a CC-BY-NC-ND 4.0 International license .

SUBGROUPING BASED ON CO-OCCURRING PSYCHOPATHOLOGY

disorders emerge, transitioning from risk to disorder as children undergo physiological and neurodevelopmental changes (e.g., puberty) and are exposed to a myriad of environmental stimuli (e.g., interactions with caregivers at home, teacher and peer interactions at school)—can be formed based solely on patterns of psychopathology (Solmi et al., 2021).

The presentation of co-occurring psychopathology in children with ASD is complex and can be influenced by various factors, such as cognitive ability, sleep duration, and medical history. Regarding cognitive ability, some studies show that children with ASD and cognitive impairment experience more anxiety and exhibit more challenging behaviors (Bradley et al., 2004; O'Brien \& Pearson, 2004; Murphy et al., 2009), while others suggest more internalizing and externalizing problems in those with average or above average cognitive ability (Gadow et al., 2005; Gadow et al., 2008b; van Steensel et al. 2011; Gjevik et al., 2011; Strang et al., 2012). With regard to sleep duration, sleep disturbances, especially insomnia, have been associated with increased internalizing and externalizing problems, namely attention difficulties, anxiety, and mood dysregulation, in children with ASD (Park et al., 2012; Richdale \& Baglin, 2015; Veatch et al., 2017).

It is estimated that $10-77 \%$ of children with ASD have a co-occurring medical condition, with gastrointestinal disorders, neurological disorders, and allergies/autoimmune disorders being among the most well-studied (Muskens, et al., 2017). The presence of medical conditions, especially gastrointestinal and neurological disorders, has also been positively associated with internalizing and externalizing problems in children with ASD (Gadow et al., 2008b; Simonoff et al., 2008; Mannion \& Leader, 2013; Mazefsky et al., 2014; Fulceri et al., 2016; Weber \& Gadow, 2017; Restrepo et al., 2020). However, several studies have not found significant associations between other medical conditions (e.g., allergies/autoimmune disorders) and co-occurring psychopathology in children with ASD (Ming et al., 2008; Weber \& Gadow, 2017). Considering these mixed findings, more research is needed to investigate the relationship between child-level factors and co-occurring psychopathology, especially that in the form of psychopathology-based subgroups.

In addition, age and sex have been shown to differentially affect the presentation of co-occurring psychopathology in children with ASD. Older children seem to be at higher risk for internalizing and externalizing problems than younger children (Fodstad et al., 2010; Salazar et al., 2015; Soke et al., 
medRxiv preprint doi: https://doi.org/10.1101/2021.07.19.21260784; this version posted December 1, 2021. The copyright holder for this preprint (which was not certified by peer review) is the author/funder, who has granted medRxiv a license to display the preprint in perpetuity.

It is made available under a CC-BY-NC-ND 4.0 International license .

SUBGROUPING BASED ON CO-OCCURRING PSYCHOPATHOLOGY

2018), meanwhile more internalizing problems are reported in females, and more externalizing problems are reported in males (Giarelli et al. 2010; Solomon et al., 2012; Salazar et al., 2015). These studies imply that age and sex should be carefully controlled during investigations of co-occurring psychopathology in children with ASD. Lastly, there is emerging but inconsistent evidence of a relationship between ASD symptom severity and co-occurring psychopathology, cognitive impairment, sleep disturbance, and medical conditions, with studies reporting positive (Yoshida \& Uchiyama, 2004; Jang et al., 2010; Snow \& Lecavalier, 2011; Wang et al., 2011; Ewen et al., 2019; Lindor et al., 2019) and negative (Mosner et al., 2020) relationships as well as no relationship (Simonoff et al., 2013; Louwerse et al., 2015; Lindor et al., 2019). Therefore, studies probing whether these factors influence the presentation of co-occurring psychopathology should control for ASD symptom severity.

The purpose of this study was to derive subgroups of school-aged children with ASD based on the presence of co-occurring psychopathology—psychiatric symptoms that surpass cutoffs on the Child Behavior Checklist for Ages 6 to 18 (CBCL 6/18)—while controlling for age and sex and to use multinomial logistic regression, controlling for ASD symptom severity, to examine predictors of subgroup membership, focusing on the presence of cognitive impairment, sleep disturbance, and three groups of medical conditions: allergies/autoimmune disorders, gastrointestinal disorders, and neurological disorders.

\section{Methods}

\section{Participants}

Data were obtained from the Simons Simplex Collection (SSC; version 15). The data collection process has been described in detail elsewhere (Fischbach \& Lord, 2010) and briefly summarized below. Phenotypic data were collected over a six-month period from more than 2,700 families that were already receiving services from one of twelve university-affiliated clinics. Each family was composed of a single child with ASD (i.e., the proband), their unaffected parents, and their unaffected sibling(s). To be included in the SSC, probands needed to be English-speaking, older than four years old, and younger than 18 years old. They also needed to have a best-estimate diagnosis of ASD and surpass designated cutoffs on the ADI-R, the ADOS, and a measure of nonverbal cognitive ability. Informed consent was obtained at each data collection site included in the SSC. 
medRxiv preprint doi: https://doi.org/10.1101/2021.07.19.21260784; this version posted December 1, 2021. The copyright holder for this preprint (which was not certified by peer review) is the author/funder, who has granted medRxiv a license to display the preprint in perpetuity.

It is made available under a CC-BY-NC-ND 4.0 International license .

SUBGROUPING BASED ON CO-OCCURRING PSYCHOPATHOLOGY

Figure 1 illustrates the participant selection process for all analyses. Our original analytic sample consisted of 2,184 school-aged children with ASD (aged six to 18 years old) whose caregivers had completed a CBCL/6-18. For the LCA, 97 (4.44\%) of the participants were excluded because they had missing indicator variable data and/or covariate data (described below), resulting in a sample of 2,087 $(95.56 \%)$ children. Further, $36(1.72 \%$ of 2,087$)$ participants from the LCA sample were excluded from the multinomial logistic regression due to missing predictor variable data, resulting in a sample of 2,051 (93.91\%) children. An additional $97(4.73 \%$ of 2,051$)$ participants were excluded from this analysis because they were considered outliers, having standardized residuals $>|2|$ and therefore violating the assumptions of multinomial logistic regression. Thus, the final sample consisted of $1,954(89.47 \%)$ children.

\section{Measures}

\section{Indicator Variables}

The presence of co-occurring psychopathology was determined using the DSM-Oriented Scales of the caregiver-report form of the CBCL/6-18. The scales are comprised of items that describe specific problem behaviors and are first rated 0 (not true) to 2 (often or very true) by caregivers and then converted to $T$-scores based on raw score totals. Although the DSM-Oriented Scales are dimensional measures of symptom levels, for the purpose of the current analysis, we dichotomized $T$-scores based on the recommended cutoffs separating the borderline/clinical (elevated levels of psychopathology defined by $T$-scores $\geq 65$ ) and normal ranges (absence of psychopathology defined by $T$-scores $<65$ ) (Achenbach \& Rescorla, 2001). We estimated latent class models using five of the six DSM-Oriented Scales: ADHD Problems, Affective Problems, Anxiety Problems, Conduct Problems, and Oppositional Defiant Problems. We excluded the Somatic Problems scale from our analysis given previously-reported concerns around its psychometric properties (Ebesutani et al., 2009) and its overlap with other scales. We also conducted a sensitivity analysis, using all six scales as indicator variables in our LCA and found little added value when the Somatic Problems scale was included (Supplementary Table 1;

Supplementary Figure 1) and observed substantial agreement between class assignments from LCAs with and without the Somatic Problems scale (kappa > 0.80; Cohen, 1960).

\section{Predictor Variables}


medRxiv preprint doi: https://doi.org/10.1101/2021.07.19.21260784; this version posted December 1, 2021. The copyright holder for this preprint (which was not certified by peer review) is the author/funder, who has granted medRxiv a license to display the preprint in perpetuity. It is made available under a CC-BY-NC-ND 4.0 International license .

SUBGROUPING BASED ON CO-OCCURRING PSYCHOPATHOLOGY

Nonverbal IQ was assessed using one of four measures included in the SSC data collection process, the Mullen Scales of Early Learning (Mullen, 1995), the Differential Ability Scales-II (Elliott, 2007), the Wechsler Intelligence Scale for Children-IV, or the Wechsler Abbreviated Scale of Intelligence (Mullen, 1995; Wechsler, 1999; Weschler, 2003). Of note, for the Mullen, NVIQ was calculated by averaging ageequivalent scores from the Fine Motor and Visual Reception scales, dividing this average by the child's chronological age, and multiplying this quotient by 100 (Bishop et al., 2011). The presence of sleep disturbance was determined by following the methods of a previous SSC study (Veatch et al., 2017); children whose current sleep duration fell outside of the recommended age-based ranges, per the American Academy of Pediatrics (Paruthi et al., 2016), were considered to have a sleep disturbance. A manually cleaned version of this variable has been made available (Supplementary Table 8).

Information about medical history was obtained from the SSC's medical history form, indicating whether or not participants had ever had a given condition, as reported by their caregiver(s). We grouped conditions into larger categories based on the organization of the SSC's medical history form and a previous study (Croen et al., 2015; Supplementary Tables 2 and 3). While we started with nine groups in total-“Allergies/Autoimmune Disorders," "Cancer," "Chronic Illnesses," "Diseases \& Surgeries," "Gastrointestinal Disorders," "Genetic Disorders," "Hearing and Vision Problems," "Heart Disease," and "Neurological Disorders"-we ultimately included the three that were most relevant to co-occurring psychopathology in children with ASD based on a previous study (Muskens et al., 2017; see Supplementary Table 2 for each group's endorsement rate). The variables representing these three groups were coded dichotomously, with 1 indicating that a participant had a history of at least one of the conditions within the category (i.e., responses of "true" or "diagnosed" on the SSC's medical history form) and 0 indicating that a participant did not have a history of any condition within the category (i.e., responses of "false" or "no" on the SSC's medical history form). Ambiguous responses, such as "not sure" or "suspected," were also coded as 0 . If all the conditions in the category were missing responses, the category was coded as "NA." The conditions in all three groups are displayed in Supplementary Table 3. The individual conditions with the highest endorsement rates in each category were: allergies and/or reactions to the environment (27.31\%), food (14.37\%), and medication (13.90\%), asthma $(10.30 \%)$, 
medRxiv preprint doi: https://doi.org/10.1101/2021.07.19.21260784; this version posted December 1, 2021. The copyright holder for this preprint (which was not certified by peer review) is the author/funder, who has granted medRxiv a license to display the preprint in perpetuity.

It is made available under a CC-BY-NC-ND 4.0 International license .

SUBGROUPING BASED ON CO-OCCURRING PSYCHOPATHOLOGY

constipation (18.30\%), diarrhea (6.71\%), gastroesophageal reflux (6.61\%), unusual stools $(5.56 \%)$, excessively clumsy/uncoordinated $(8.10 \%)$, and seizures $(5.61 \%)$.

\section{Covariates}

Age was approximated using participants' age at ADOS administration. ASD symptom severity was captured using the ADOS's Calibrated Severity Scores (Gotham et al., 2009). Because CSS data couldn't be calculated for Module 4 participants at the time of collection, and were thus missing, we calculated CSS data for Module 4 participants based on the revised algorithm and added these data to our analysis (Hus \& Lord, 2014).

\section{Statistical Analyses}

LCA was performed in R (version 4.0.4) using the poLCA package (Linzer \& Lewis, 2013). Latent class models with one through six classes were estimated based on five binary indicator variables (the CBCL/6-18's DSM-Oriented Scales): ADHD problems, affective problems, anxiety problems, conduct problems, and oppositional defiant problems. Age and sex were included in the models as covariates. Comparisons between models were made using goodness-of-fit criteria, including the Akaike information criterion (AIC), the Bayesian information criterion (BIC), and entropy. Lower AIC and BIC values and higher entropy values indicate better model fit. Additional goodness-of-fit criteria (e.g., Gsq, Llik, cAIC, aBIC) are reported in Supplementary Table 4. Models were also evaluated for interpretability (i.e., whether the derived classes were clinically relevant and distinguishable). Posterior probabilities were used to assign participants to their most likely class. Multinomial logistic regression was performed in SPSS (version 27; IBM Corporation, Armonk, NY) to investigate whether the derived classes could be predicted by five variables-nonverbal IQ $(\mathrm{NVIQ})<70$, sleep disturbance, allergies/autoimmune disorders, gastrointestinal disorders, or neurological disorders-while controlling for ASD symptom severity (measured by ADOS CSS data). Residual analysis was used to check relevant assumptions: linearity, normality, and homogeneity of variance. Multicollinearity was checked using Cramer's V. All the scripts used to run the analyses can be found here:

https://osf.io/xyvc2/?view only=736ea37d02404383bc9125745e3c2391.

\section{Results}


medRxiv preprint doi: https://doi.org/10.1101/2021.07.19.21260784; this version posted December 1, 2021. The copyright holder for this preprint (which was not certified by peer review) is the author/funder, who has granted medRxiv a license to display the preprint in perpetuity.

It is made available under a CC-BY-NC-ND 4.0 International license .

SUBGROUPING BASED ON CO-OCCURRING PSYCHOPATHOLOGY

For the entire LCA sample $(n=2,087)$, the mean age was 10.30 years (range: $6-18, S D=3.12)$ and 1,808 (86.63\%) participants were male (Table 1). Additionally, the sample included $516(24.72 \%)$ participants who had NVIQs $<70(M=84.48, \mathrm{SD}=26.28), 501(24.01 \%)$ participants experiencing sleep disturbances, 992 (47.53\%) who had histories of at least one allergy/autoimmune disorder, 664 (31.82\%) who had histories of at least one gastrointestinal disorder, and $517(24.77 \%)$ who had histories of at least one neurological disorder.

\section{[INSERT TABLE 1]}

\section{Latent Class Analysis}

The results of the LCA (Table 2), which controlled for age and sex, showed that a four-class model was optimal, with the smallest AIC and BIC. None of the entropy values were close to zero, indicating that classes were well-separated (Zhang et al., 2018). The four-class model (Figure 2) showed clear differentiation between co-occurring psychopathology patterns among children and adolescents with ASD, the characteristics of which are summarized in Table 3. We also performed an LCA which repeated model estimation 1,000 times using a subset of 1,000 participants as a validation sample, which suggested either a three- or four-class solution (Supplementary Table 4, Figure 2). The "Low Psychopathology" subgroup was characterized by the lowest percentage of participants with borderline/clinical levels of all problems. Compared to the "Low Psychopathology" subgroup, the "Externalizing Problems" subgroup had more participants with borderline/clinical levels of all problems, mainly ADHD, conduct, and oppositional defiant problems. The "Internalizing Problems" subgroup had fewer participants with borderline/clinical levels of ADHD, conduct, and oppositional defiant problems but more participants with borderline/clinical levels of affective and anxiety problems than the "Externalizing Problems" subgroup. The "High Psychopathology" subgroup was characterized by the highest percentage of participants with borderline/clinical levels of all problems.

\section{[INSERT TABLE 2]}

\section{[INSERT FIGURE 2]}

\section{Multinomial Logistic Regression}

The results of the multinomial logistic regression are presented in Table 3. Comparisons were made while controlling for ASD symptom severity and using the "Low Psychopathology" subgroup as the 
medRxiv preprint doi: https://doi.org/10.1101/2021.07.19.21260784; this version posted December 1, 2021. The copyright holder for this preprint (which was not certified by peer review) is the author/funder, who has granted medRxiv a license to display the preprint in perpetuity. It is made available under a CC-BY-NC-ND 4.0 International license .

SUBGROUPING BASED ON CO-OCCURRING PSYCHOPATHOLOGY

reference. $\mathrm{NVIQ}<70(p<.001)$, sleep disturbance $(p<.001)$, allergies/autoimmune disorders $(p<.05)$, gastrointestinal disorders $(p<.001)$, and neurological disorders $(p<.001)$ were all found to be significant predictors of subgroup membership. Moreover, almost all these variables were significantly associated with belonging to the three subgroups characterized by elevated borderline/clinical levels of problems. $\mathrm{NVIQ}<70$, sleep disturbance, gastrointestinal disorders, and neurological disorders were the strongest predictors of subgroup membership, making participants approximately twice as likely to belong to one of these subgroups. Relative to the "Low Psychopathology" subgroup, children with NVIQs $<70$ were less likely to belong to the "Internalizing Problems" (OR =.63, $p=<.001)$ or the "High Psychopathology" (OR $=.42, p<.001)$ subgroups. Children with sleep disturbance and histories of at least one gastrointestinal disorder were more likely to belong to the "Externalizing Problems" $(\mathrm{OR}=2.07, p=<.001 ; \mathrm{OR}=2.11, p$ $=<.001)$ and "High Psychopathology" (OR $=2.15, p=<.001$; OR $=1.90, p=<.001)$ subgroups than the "Low Psychopathology" subgroup, whereas children with histories of at least one neurological disorder were more likely to belong to the "Externalizing Problems" subgroup alone (OR $=2.15, p=<.001)$.

[INSERT TABLE 3]

\section{Discussion and Implications}

\section{Discussion}

The current study is the first to use LCA to derive subgroups of school-aged children with ASD based on patterns of co-occurring psychopathology while controlling for age and sex. We identified four subgroups, characterized by low psychopathology, externalizing problems, internalizing problems, and high psychopathology. Using multinomial logistic regression, while controlling for ASD symptom severity, we also established the predictive value of $\mathrm{NVIQ}<70$, sleep disturbance, and three groups of medical conditions- allergies/autoimmune disorders, gastrointestinal disorders, and neurological disorders-for subgroup membership.

The "Low Psychopathology" subgroup (41.02\%) was the largest subgroup in our sample, suggesting that less than half of school-aged children with ASD are within the normal range for most, if not all, psychiatric symptoms measured by the $\mathrm{CBCL} / 6-18$. This rate is similar to rates of "no psychiatric diagnosis" in other ASD samples (37.2\%; Simonoff et al., 2008). In terms of size, the "Low Psychopathology" subgroup was followed by the "Internalizing Problems" subgroup (31.58\%), which was 
medRxiv preprint doi: https://doi.org/10.1101/2021.07.19.21260784; this version posted December 1, 2021. The copyright holder for this preprint (which was not certified by peer review) is the author/funder, who has granted medRxiv a license to display the preprint in perpetuity. It is made available under a CC-BY-NC-ND 4.0 International license .

unsurprising given that anxiety (44.85\%) and affective (38.76\%) problems were the most common psychiatric symptoms in our sample. However, this rate is lower than previously reported rates of anxiety (56\%) and depression (44\%) in children with ASD (Strang et al., 2012). This discrepancy could be due to the fact that $15.05 \%$ of our sample belonged to the "High Psychopathology" subgroup, which is characterized by high rates of both internalizing and externalizing problems. The "Externalizing Problems" subgroup (12.3\%) was the smallest subgroup in our sample.

To contextualize our findings within the literature, we compared our results to those of a similar LCA study, which used clinically-referred and general-population samples of school-aged children to derive four psychopathology-based subgroups with CBCL/6-18 data (Bianchi et al., 2017). There were several key differences. First, our study identified a subgroup characterized by multiple, highly endorsed externalizing problems: ADHD (56.59\%), conduct (62.79\%), and oppositional defiant (68.60\%) problems. Bianchi and colleagues' study lacks such a subgroup. Instead, their study identified an "ADHD” subgroup, in which $\sim 70 \%$ of children had attention problems in the borderline/clinical range but relatively few other problems. Interestingly, our "Internalizing Problems" and "High Psychopathology" subgroups had high endorsement rates of ADHD problems $(40.52 \%$ and $85.53 \%$, respectively) as well, suggesting that children with ASD who present with ADHD symptoms will likely present with additional psychiatric symptoms. Observing moderate-to-high endorsement rates of ADHD problems in the "Externalizing Problems," "Internalizing Problems," and "High Psychopathology" subgroups (range: 40.52-81.53\%), and an endorsement rate of $16.12 \%$ in the "Low Psychopathology" subgroup, is consistent with the literature, as ASD and ADHD co-occur at rates greater than chance (Miller et al., 2019), and having ADHD in addition to ASD might increase risk for other forms of psychopathology, such as anxiety (Gadow et al., 2009), aggression, delinquent behavior, and thought problems (Matsushima et al., 2008). Indeed, the most common combination of co-occurring psychiatric disorders in children with ASD are ADHD, anxiety disorders, and ODD (Brookman-Frazee et al., 2018).

Second, our study had a higher percentage of participants belonging to each subgroup characterized by elevated problems, suggesting that children with ASD are at increased risk for psychopathology compared to other populations of children; our "Low Psychopathology" subgroup (41.02\%) was 25\% smaller than Bianchi and colleagues' equivalent (66.32\%), and our "High Psychopathology" subgroup 
medRxiv preprint doi: https://doi.org/10.1101/2021.07.19.21260784; this version posted December 1, 2021. The copyright holder for this preprint (which was not certified by peer review) is the author/funder, who has granted medRxiv a license to display the preprint in perpetuity. It is made available under a CC-BY-NC-ND 4.0 International license .

SUBGROUPING BASED ON CO-OCCURRING PSYCHOPATHOLOGY

(15.05\%) was over double the size of Bianchi and colleagues' "Severe Dysregulated" subgroup (7.82\%). While our "Externalizing Problems" subgroup (12.36\%) was only slightly larger than Bianchi and colleagues' “ADHD” subgroup (10.19\%), our "Internalizing Problems" subgroup was substantially larger than theirs (31.58\% to $15.68 \%)$, which is in agreement with previous studies reporting higher rates of anxiety and depression in individuals with ASD than those in the general population (White et al., 2009; Kim \& Lecavalier, 2021). In sum, our findings demonstrate increased prevalence of complex psychiatric symptoms in children with ASD as compared to children without ASD, with symptoms of ADHD often cooccurring with other externalizing and internalizing problems.

Using multinomial logistic regression, we found that cognitive impairment and sleep disturbance were associated with subgroup membership. Specifically, we found that children with NVIQs $<70$ were about half as likely to belong to the "Internalizing Problems" or "High Psychopathology" subgroups than the "Low Psychopathology" subgroup, which is consistent with previous studies showing that individuals with ASD and average or above average cognitive ability are at greater risk for certain psychiatric disorders, such as anxiety and depression, than those with cognitive impairment (Lecavalier, 2006; Hallett et al., 2013a; Sukhodolsky et al. 2008; Mazurek \& Kanne 2010). Because NVIQ < 70 was a unique predictor of "Internalizing Problems" and "High Psychopathology" subgroup membership, our results could be driven by data from participants with NVIQs $\geq 70$, who make up over $75 \%$ of our sample. Indeed, mean NVIQ was highest for "Internalizing Problems" subgroup (87.08), followed by the "High Psychopathology" subgroup (85.02), and then the "Externalizing Problems" (84.53) and "Low Psychopathology" (82.88) subgroups. It is also possible that difficulties understanding and expressing complex mental states, such as subjective, emotional experiences, is contributing to an underestimation of caregiver-reported psychiatric symptoms in children with ASD and NVIQs $<70$ (Simonoff et al., 2008; van Steensel et al., 2017), as the directionality of the relationship between cognitive ability and psychopathology appears to be informant-dependent (Gadow et al., 2008b; Hallet et al., 2013b). Thus, future studies should use alternative strategies to measure psychiatric symptoms in children with ASD who vary in cognitive ability. For example, objective measures, such as physiological data, could help clinicians and researchers capture emotional and behavioral responses in children with ASD and lower NVIQs (Kushki et al., 2013). Alternatively, children with average or above average cognitive ability may 
medRxiv preprint doi: https://doi.org/10.1101/2021.07.19.21260784; this version posted December 1, 2021. The copyright holder for this preprint (which was not certified by peer review) is the author/funder, who has granted medRxiv a license to display the preprint in perpetuity. It is made available under a CC-BY-NC-ND 4.0 International license .

SUBGROUPING BASED ON CO-OCCURRING PSYCHOPATHOLOGY

be more aware of their ASD-related challenges, and this awareness could be a risk factor for psychopathology (Sterling et al., 2008). Finally, parents may be overestimating psychiatric symptoms in children with average or above average cognitive ability (Nicpon et al., 2010).

Sleep disturbance most strongly predicted membership to the "Externalizing Problems" and "High Psychopathology" subgroups. This finding is in line with the results of Adams and colleagues' (2014) study, in which increased severity of sleep disturbance was positively associated with externalizing and total (i.e., internalizing and externalizing) problems. Insomnia, the more highly endorsed type of sleep disturbance in our study, has been linked to impaired prefrontal cortex, basal ganglia, and amygdala functioning, which could be causing difficulties with executive functioning, reward anticipation, and emotional reactivity, leading to externalizing problems or overall high psychopathology (Maski \& Kothare, 2013).

Additionally, using multinomial logistic regression, we found that subgroup membership was most strongly predicted by having a history of at least one gastrointestinal disorder and a history of at least one neurological disorder. This finding complements other studies in the literature that have found a relationship between these medical conditions and any one psychiatric disorder in children with ASD by adding a novel contribution: demonstrating that a history of these medical conditions predicts unique patterns of the combined presence/absence of psychiatric symptoms (Gadow et al., 2008b; Simonoff et al., 2008; Mannion \& Leader, 2013; Mazefsky et al., 2014; Fulceri et al., 2016; Weber \& Gadow, 2017; Restrepo et al., 2020). Our findings are consistent with two studies on how these conditions affect internalizing and externalizing problems in children with ASD. The first study found more anxiety problems, externalizing problems, and total problems in young children with gastrointestinal symptoms compared to those without symptoms (Fulceri at al., 2016), which is consistent with our finding that having a history of at least one gastrointestinal disorder roughly doubles one's likelihood of belonging to the "Externalizing Problems" and "High Psychopathology" subgroups over the "Low Psychopathology" subgroup. The second study found that having epilepsy, one of the neurological disorders included in our study, resulted in an increased likelihood of having the psychiatric disorders that correspond to our "Externalizing Problems" and "High Psychopathology" subgroups (i.e., ADHD, oppositional defiant or conduct disorder, and any emotional disorder) by $\sim 11$ - and 17-fold, respectively (Simonoff et al., 2008). In 
medRxiv preprint doi: https://doi.org/10.1101/2021.07.19.21260784; this version posted December 1, 2021. The copyright holder for this preprint (which was not certified by peer review) is the author/funder, who has granted medRxiv a license to display the preprint in perpetuity. It is made available under a CC-BY-NC-ND 4.0 International license .

SUBGROUPING BASED ON CO-OCCURRING PSYCHOPATHOLOGY

our study, having a history of at least one neurological disorder strongly predicted "Externalizing Problems" subgroup membership, increasing a child's likelihood by about two-fold. One possible explanation for the difference in the magnitude of our study's and this study's odds ratios is that we included a broader range of neurological disorders (16 conditions, Supplementary Table 3 ), whereas Simonoff and colleagues focused solely on epilepsy.

Our study has several limitations. First, we used a categorical framework to conceptualize psychopathology. Though dichotomizing a dimensional measure (i.e., the DSM-Oriented Scales) likely resulted in the loss of information on symptom levels, we chose to do so in order to make our findings directly relevant to clinical practice by focusing on the presence or absence of borderline/clinical-range psychiatric problems. Second, psychiatric symptoms may present differently in children with ASD and/or cognitive impairment (Kerns et al., 2012), and some symptoms may not reflect the same constructs as they do in typically developing (Rodriguez-Seijas et al., 2019) or other clinical populations (Sinzig et al., 2009). Additionally, although the CBCL's DSM-Oriented Scales were designed to map on to a wide range of specific disorders of the DSM-V, including major depressive disorder, persistent depressive disorder, generalized anxiety disorder, separation anxiety disorder, social anxiety disorder, specific phobia, ADHD, oppositional defiant disorder, and conduct disorder, they are not all-encompassing. Further, we defined sleep disturbance solely based on abnormal sleep duration. Therefore, our study may have failed to capture some psychiatric symptoms and co-occurring problems in this population. Third, the crosssectional nature of the SSC sample does not allow for the evaluation of causal relationships between our predictor variables and psychopathology-based subgroups. Such relationship is likely bidirectional and warrants longitudinal investigation. Fourth, given the nature of the SSC sample and LCA, our findings may not be widely generalizable to all children with ASD. Specifically, inclusion in the SSC was based on strict ADI-R and ADOS cut-offs, and participants received their best-estimate diagnosis of ASD over a decade ago. We want to warn fellow clinicians and researchers that our findings should be interpreted with the sampling method in mind and may not fully represent the range of psychiatric symptoms in the ASD population due to changing diagnostic criteria and referral processes (Lai et al., 2015; Lord et al., 2018; CDC, 2021). Moreover, LCA is a model-based subgrouping approach, and the best fitting model is determined based on the available data, limiting the generalizability to other samples. However, our large 
medRxiv preprint doi: https://doi.org/10.1101/2021.07.19.21260784; this version posted December 1, 2021. The copyright holder for this preprint (which was not certified by peer review) is the author/funder, who has granted medRxiv a license to display the preprint in perpetuity. It is made available under a CC-BY-NC-ND 4.0 International license .

SUBGROUPING BASED ON CO-OCCURRING PSYCHOPATHOLOGY

sample size (over 2,000 individuals with ASD) and use of age, sex, and ASD symptom severity as covariates add to the strengths of our study, which was effective at capturing the individual profiles of cooccurring psychopathology that exist within our sample and predictors of such profiles.

\section{Implications}

The findings of this study have important implications for clinical practice and research. First, the four subgroups derived from our sample demonstrate a need for clinicians to be cognizant of co-occurring internalizing and externalizing problems in school-aged children with ASD and the potential impact of these psychiatric symptoms on diagnostic tools used to identify ASD. In other words, when a clinician is evaluating a school-aged child for ASD, it is possible that the child will be exhibiting certain patterns of cooccurring psychopathology that could affect their interpretation of ASD symptom measures. Our findings also reinforce the need for multidisciplinary services in this population, suggesting that non-ASD specialists (e.g., primary care physicians) consider co-occurring psychopathology when they are providing care for children with ASD. For example, based on our study's subgroups, when seeing a child with ASD and a combination of sleep disturbances, gastrointestinal disorders, and/or neurological disorders, a pediatrician may want to collaborate with a mental health provider, as this child might be at particularly high risk for externalizing problems, whereas a child with a NVIQ $<70$ could be suspectable to internalizing problems, and a child with a NVIQ $<70$, a sleep disturbance, and/or a gastrointestinal disorder may be vulnerable to both internalizing and externalizing problems. Psychopathology-based subgroups also affect responses to intervention and should be carefully considered in the development of intervention guidelines, which are currently broad (i.e., non-specific to subpopulations), and in future studies on how different subpopulations of children with ASD respond to interventions targeting core and associated symptoms (Antshel et al., 2011; McBride et al., 2020; Dekker et al., 2021; Wickstrom et al., 2021). For example, light therapy could be beneficial to children belonging to a "High Psychopathology" subgroup, who are at elevated risk for depression and sleep disturbances (Fritzsche et al., 2001). Finally, the findings of this study provide additional rationale to investigate the shared mechanisms between psychiatric disorders as well as psychiatric disorders and co-occurring problems. The subgroups derived in this study should be carefully considered when generating hypotheses for etiology-driven research on psychiatric symptoms and co-occurring problems. Since the SSC has genetic data available, future 
medRxiv preprint doi: https://doi.org/10.1101/2021.07.19.21260784; this version posted December 1, 2021. The copyright holder for this preprint (which was not certified by peer review) is the author/funder, who has granted medRxiv a license to display the preprint in perpetuity.

It is made available under a CC-BY-NC-ND 4.0 International license .

SUBGROUPING BASED ON CO-OCCURRING PSYCHOPATHOLOGY

studies could replicate our subgroups and directly examine potential transdiagnostic mechanisms. For example, several studies have suggested shared genetic contributions to ASD and ADHD phenotypes as well as ASD, depression, and anxiety phenotypes (Ronald et al., 2014; Ruparelia et al., 2017). Studies have also suggested overlap in genetic risk factors for ASD, intellectual disability, sleep disturbance, and medical conditions (Veatch et al., 2015; Jeste \& Geschwind, 2014). In conclusion, our findings indicate that there are unique patterns of psychopathology among school-aged children with ASD which are associated with cognitive impairment, sleep disturbance, and medical conditions. To improve the ways in which we support children with ASD and co-occurring psychopathology, we argue that professionals should go beyond the diagnosis of ASD and consider an individual's compressive symptom profile when diagnosing, treating, and researching this population.

\section{Acknowledgements}

Dr. Monden was partially supported by the Clinical Investigator's Research Project at Osaka University's Graduate School of Medicine. Many thanks to Drs. Caroline Lew and Jordan Wickstrom for their valuable feedback on drafts. We are grateful to all of the families at the participating Simons Simplex Collection (SSC) sites, as well as the principal investigators (A. Beaudet, R. Bernier, J. Constantino, E. Cook, E. Fombonne, D. Geschwind, R. Goin-Kochel, E. Hanson, D. Grice, A. Klin, D. Ledbetter, C. Lord, C. Martin, D. Martin, R. Maxim, J. Miles, O. Ousley, K. Pelphrey, B. Peterson, J. Piggot, C. Saulnier, M. State, W. Stone, J. Sutcliffe, C. Walsh, Z. Warren, E. Wijsman). We also appreciate obtaining access to phenotypic data on SFARI Base. Approved researchers can obtain the SSC population datasets described in this study by applying at https://base.sfari.org.

\section{Conflicts of Interest}

There are no conflicts of interest for the authors to disclose. 
medRxiv preprint doi: https://doi.org/10.1101/2021.07.19.21260784; this version posted December 1, 2021. The copyright holder for this preprint (which was not certified by peer review) is the author/funder, who has granted medRxiv a license to display the preprint in perpetuity.

It is made available under a CC-BY-NC-ND 4.0 International license .

SUBGROUPING BASED ON CO-OCCURRING PSYCHOPATHOLOGY

\section{References}

Adams, H. L., Matson, J. L., \& Jang, J. (2014). The relationship between sleep problems and challenging behavior among children and adolescents with autism spectrum disorder. Research in Autism Spectrum Disorders, 8(9), 1024-1030. https://doi.org/10.1016/j.rasd.2014.05.008

Bianchi, V., Brambilla, P., Garzitto, M., Colombo, P., Fornasari, L., Bellina, M., Bonivento, C., Tesei, A., Piccin, S., Conte, S., Perna, G., Frigerio, A., Castiglioni, I., Fabbro, F., Molteni, M., \& Nobile, M. (2017). Latent classes of emotional and behavioural problems in epidemiological and referred samples and their relations to DSM-IV diagnoses. European Child \& Adolescent Psychiatry, 26(5), 549-557. https://doi.org/10.1007/s00787-016-0918-2

Bishop, S. L., Guthrie, W., Coffing, M., \& Lord, C. (2011). Convergent Validity of the Mullen Scales of Early Learning and the Differential Ability Scales in Children With Autism Spectrum Disorders. American Journal on Intellectual and Developmental Disabilities, 116(5), 331-343. https://doi.org/10.1352/19447558-116.5.331

Bradley, E. A., Summers, J. A., Wood, H. L., \& Bryson, S. E. (2004). Comparing Rates of Psychiatric and Behavior Disorders in Adolescents and Young Adults with Severe Intellectual Disability with and without Autism. Journal of Autism and Developmental Disorders, 34(2), 151-161.

https://doi.org/10.1023/B:JADD.0000022606.97580.19

Brookman-Frazee, L., Stadnick, N., Chlebowski, C., Baker-Ericzén, M., \& Ganger, W. (2018). Characterizing psychiatric comorbidity in children with autism spectrum disorder receiving publicly funded mental health services. Autism, 22(8), 938-952. https://doi.org/10.1177/1362361317712650

Chandrasekhar, T., \& Sikich, L. (2015). Challenges in the diagnosis and treatment of depression in autism spectrum disorders across the lifespan. Dialogues in Clinical Neuroscience, 17(2), 219-227. https://www.ncbi.nIm.nih.gov/pmc/articles/PMC4518704/

Center for Disease Control and Prevention. Autism and Developmental Disabilities Monitoring Network Community Report on Autism 2020. Published October 2, 2020. Accessed February 2, 2021. https://www.cdc.gov/ncbddd/autism/addm-community-report/index.html 
medRxiv preprint doi: https://doi.org/10.1101/2021.07.19.21260784; this version posted December 1, 2021. The copyright holder for this preprint (which was not certified by peer review) is the author/funder, who has granted medRxiv a license to display the preprint in perpetuity. It is made available under a CC-BY-NC-ND 4.0 International license .

Christopher, K., Bishop, S., Carpenter, L. A., Warren, Z., \& Kanne, S. (2021). The Implications of ParentReported Emotional and Behavioral Problems on the Modified Checklist for Autism in Toddlers. Journal of Autism and Developmental Disorders, 51(3), 884-891. https://doi.org/10.1007/s10803-020-04469-5

Colombi, C., Fish, A., \& Ghaziuddin, M. (2020). Utility of the ADOS-2 in children with psychiatric disorders. European Child \& Adolescent Psychiatry, 29(7), 989-992. https://doi.org/10.1007/s00787-019-01411-8

Croen, L. A., Zerbo, O., Qian, Y., Massolo, M. L., Rich, S., Sidney, S., \& Kripke, C. (2015). The health status of adults on the autism spectrum. Autism, 19(7), 814-823. https://doi.org/10.1177/1362361315577517 de Bildt, A., Sytema, S., Kraijer, D., Sparrow, S., \& Minderaa, R. (2005). Adaptive functioning and behaviour problems in relation to level of education in children and adolescents with intellectual disability. Journal of Intellectual Disability Research, 49(9), 672-681. https://doi.org/10.1111/j.1365-2788.2005.00711.x

Dekker, V., Nauta, M. H., Timmerman, M. E., Mulder, E. J., Hoekstra, P. J., \& de Bildt, A. (2021). Application of Latent Class Analysis to Identify Subgroups of Children with Autism Spectrum Disorders who Benefit from Social Skills Training. Journal of Autism and Developmental Disorders, 51(6), 2004-2018. https://doi.org/10.1007/s10803-020-04678-y

Doshi-Velez, F., Ge, Y., \& Kohane, I. (2014). Comorbidity Clusters in Autism Spectrum Disorders: An Electronic Health Record Time-Series Analysis. Pediatrics, 133(1), e54-e63. https://doi.org/10.1542/peds.2013-0819

Ewen, J. B., Marvin, A. R., Law, K., \& Lipkin, P. H. (2019). Epilepsy and Autism Severity: A Study of 6,975 Children. Autism Research, 12(8), 1251-1259. https://doi.org/10.1002/aur.2132

Fodstad, J. C., Rojahn, J., \& Matson, J. L. (2010). Emergent Comorbidity in At Risk Children with and without Autism Spectrum Disorder-A Cross-Sectional Study. Journal of Developmental and Physical Disabilities, 22(4), 381-400. https://doi.org/10.1007/s10882-010-9202-4

Fritzsche, M., Heller, R., Hill, H., \& Kick, H. (2001). Sleep deprivation as a predictor of response to light therapy in major depression. Journal of Affective Disorders, 62(3), 207-215. https://doi.org/10.1016/S0165-0327(00)00154-3

Fulceri, F., Morelli, M., Santocchi, E., Cena, H., Del Bianco, T., Narzisi, A., Calderoni, S., \& Muratori, F. (2016). Gastrointestinal symptoms and behavioral problems in preschoolers with Autism Spectrum Disorder. Digestive and Liver Disease, 48(3), 248-254. https://doi.org/10.1016/j.dld.2015.11.026 
medRxiv preprint doi: https://doi.org/10.1101/2021.07.19.21260784; this version posted December 1, 2021. The copyright holder for this preprint (which was not certified by peer review) is the author/funder, who has granted medRxiv a license to display the preprint in perpetuity.

It is made available under a CC-BY-NC-ND 4.0 International license .

Gadow, K. D., DeVincent, C. J., \& Drabick, D. A. G. (2008). Oppositional Defiant Disorder as a Clinical Phenotype in Children with Autism Spectrum Disorder. Journal of Autism and Developmental Disorders, 38(7), 1302-1310. https://doi.org/10.1007/s10803-007-0516-8

Gadow, K. D., Devincent, C. J., Pomeroy, J., \& Azizian, A. (2005). Comparison of DSM-IV symptoms in elementary school-age children with PDD versus clinic and community samples. Autism, 9(4), 392-415. https://doi.org/10.1177/1362361305056079

Gadow, K. D., DeVincent, C. J., \& Schneider, J. (2009). Comparative Study of Children With ADHD Only, Autism Spectrum Disorder + ADHD, and Chronic Multiple Tic Disorder + ADHD. Journal of Attention Disorders, 12(5), 474-485. https://doi.org/10.1177/1087054708320404

Gadow, K. D., DeVincent, C., \& Schneider, J. (2008). Predictors of Psychiatric Symptoms in Children with an Autism Spectrum Disorder. Journal of Autism and Developmental Disorders, 38(9), 1710-1720.

https://doi.org/10.1007/s10803-008-0556-8

Giarelli, E., Wiggins, L. D., Rice, C. E., Levy, S. E., Kirby, R. S., Pinto-Martin, J., \& Mandell, D. (2010). Sex differences in the evaluation and diagnosis of autism spectrum disorders among children. Disability and Health Journal, 3(2), 107-116. https://doi.org/10.1016/j.dhjo.2009.07.001

Gjevik, E., Eldevik, S., Fjæran-Granum, T., \& Sponheim, E. (2011). Kiddie-SADS Reveals High Rates of DSM-IV Disorders in Children and Adolescents with Autism Spectrum Disorders. Journal of Autism and Developmental Disorders, 41(6), 761-769. https://doi.org/10.1007/s10803-010-1095-7

Gordon-Lipkin, E., Marvin, A. R., Law, J. K., \& Lipkin, P. H. (2018). Anxiety and Mood Disorder in Children With Autism Spectrum Disorder and ADHD. Pediatrics, 141(4), e20171377. https://doi.org/10.1542/peds.2017-1377

Gotham, K., Pickles, A., \& Lord, C. (2012). Trajectories of Autism Severity in Children Using Standardized ADOS Scores. PEDIATRICS, 130(5), e1278-e1284. https://doi.org/10.1542/peds.2011-3668

Gotham, Katherine, Pickles, A., \& Lord, C. (2009). Standardizing ADOS Scores for a Measure of Severity in Autism Spectrum Disorders. Journal of Autism and Developmental Disorders, 39(5), 693-705.

https://doi.org/10.1007/s10803-008-0674-3 
medRxiv preprint doi: https://doi.org/10.1101/2021.07.19.21260784; this version posted December 1, 2021. The copyright holder for this preprint (which was not certified by peer review) is the author/funder, who has granted medRxiv a license to display the preprint in perpetuity. It is made available under a CC-BY-NC-ND 4.0 International license .

SUBGROUPING BASED ON CO-OCCURRING PSYCHOPATHOLOGY

Harris, H. K., Lee, C., Sideridis, G. D., Barbaresi, W. J., \& Harstad, E. (2021). Identifying Subgroups of Toddlers with DSM-5 Autism Spectrum Disorder Based on Core Symptoms. Journal of Autism and Developmental Disorders. https://doi.org/10.1007/s10803-021-04879-z

Havdahl, K. A., Hus Bal, V., Huerta, M., Pickles, A., Øyen, A.-S., Stoltenberg, C., Lord, C., \& Bishop, S. L. (2016). Multidimensional Influences on Autism Symptom Measures: Implications for Use in Etiological Research. Journal of the American Academy of Child \& Adolescent Psychiatry, 55(12), 1054-1063.e3. https://doi.org/10.1016/j.jaac.2016.09.490

Hus, V., \& Lord, C. (2014). The Autism Diagnostic Observation Schedule, Module 4: Revised Algorithm and Standardized Severity Scores. Journal of Autism and Developmental Disorders, 44(8), 1996-2012. https://doi.org/10.1007/s10803-014-2080-3

James, R. J. E., Dubey, I., Smith, D., Ropar, D., \& Tunney, R. J. (2016). The Latent Structure of Autistic Traits: A Taxometric, Latent Class and Latent Profile Analysis of the Adult Autism Spectrum Quotient. Journal of Autism and Developmental Disorders, 46(12), 3712-3728. https://doi.org/10.1007/s10803-0162897-z

Jeste, S. S., \& Geschwind, D. H. (2014). Disentangling the heterogeneity of autism spectrum disorder through genetic findings. Nature Reviews Neurology, 10(2), 74-81.

https://doi.org/10.1038/nrneurol.2013.278

Kaat, A. J., Gadow, K. D., \& Lecavalier, L. (2013). Psychiatric Symptom Impairment in Children with Autism Spectrum Disorders. Journal of Abnormal Child Psychology, 41(6), 959-969.

https://doi.org/10.1007/s10802-013-9739-7

Kang, E., Gadow, K. D., \& Lerner, M. D. (2020). Atypical Communication Characteristics, Differential Diagnosis, and the Autism Spectrum Disorder Phenotype in Youth. Journal of Clinical Child \& Adolescent Psychology, 49(2), 251-263. https://doi.org/10.1080/15374416.2018.1539912

Kerns, C. M., \& Kendall, P. C. (2012). The presentation and classification of anxiety in autism spectrum disorder. Clinical Psychology: Science and Practice, 19(4), 323-347. https://doi.org/10.1111/cpsp.12009

Kim, H., Keifer, C., Rodriguez-Seijas, C., Eaton, N., Lerner, M., \& Gadow, K. (2019). Quantifying the Optimal Structure of the Autism Phenotype: A Comprehensive Comparison of Dimensional, Categorical, and 
medRxiv preprint doi: https://doi.org/10.1101/2021.07.19.21260784; this version posted December 1, 2021. The copyright holder for this preprint (which was not certified by peer review) is the author/funder, who has granted medRxiv a license to display the preprint in perpetuity.

It is made available under a CC-BY-NC-ND 4.0 International license .

SUBGROUPING BASED ON CO-OCCURRING PSYCHOPATHOLOGY

Hybrid Models. Journal of the American Academy of Child \& Adolescent Psychiatry, 58(9), 876-886.e2. https://doi.org/10.1016/j.jaac.2018.09.431

Kim, J. A., Szatmari, P., Bryson, S. E., Streiner, D. L., \& Wilson, F. J. (2000). The Prevalence of Anxiety and Mood Problems among Children with Autism and Asperger Syndrome. Autism, 4(2), 117-132. https://doi.org/10.1177/1362361300004002002

Kim, S. Y., \& Lecavalier, L. (2021). Depression in young autistic people: A scoping review. Research in Autism Spectrum Disorders, 88, 101841. https://doi.org/10.1016/j.rasd.2021.101841

Kushki, A., Drumm, E., Pla Mobarak, M., Tanel, N., Dupuis, A., Chau, T., \& Anagnostou, E. (2013). Investigating the Autonomic Nervous System Response to Anxiety in Children with Autism Spectrum Disorders. PLoS ONE, 8(4), e59730. https://doi.org/10.1371/journal.pone.0059730

Lai, M.-C., Kassee, C., Besney, R., Bonato, S., Hull, L., Mandy, W., Szatmari, P., \& Ameis, S. H. (2019). Prevalence of co-occurring mental health diagnoses in the autism population: a systematic review and meta-analysis. The Lancet Psychiatry, 6(10), 819-829. https://doi.org/10.1016/S2215-0366(19)30289-5

Lai, M.-C., Lombardo, M. V., Auyeung, B., Chakrabarti, B., \& Baron-Cohen, S. (2015). Sex/Gender Differences and Autism: Setting the Scene for Future Research. Journal of the American Academy of Child \& Adolescent Psychiatry, 54(1), 11-24. https://doi.org/10.1016/j.jaac.2014.10.003

Landa, R. J., Gross, A. L., Stuart, E. A., \& Bauman, M. (2012). Latent class analysis of early developmental trajectory in baby siblings of children with autism: Latent class analysis of developmental trajectories. Journal of Child Psychology and Psychiatry, 53(9), 986-996. https://doi.org/10.1111/j.1469-

7610.2012.02558.x

Lerner, M. D., De Los Reyes, A., Drabick, D. A. G., Gerber, A. H., \& Gadow, K. D. (2017). Informant discrepancy defines discrete, clinically useful autism spectrum disorder subgroups. Journal of Child Psychology and Psychiatry, 58(7), 829-839. https://doi.org/10.1111/jcpp.12730

Levy, S. E., Giarelli, E., Lee, L.-C., Schieve, L. A., Kirby, R. S., Cunniff, C., Nicholas, J., Reaven, J., \& Rice, C. E. (2010). Autism Spectrum Disorder and Co-occurring Developmental, Psychiatric, and Medical Conditions Among Children in Multiple Populations of the United States. Journal of Developmental \& Behavioral Pediatrics, 31(4), 267-275. https://doi.org/10.1097/DBP.0b013e3181d5d03b 
medRxiv preprint doi: https://doi.org/10.1101/2021.07.19.21260784; this version posted December 1, 2021. The copyright holder for this preprint (which was not certified by peer review) is the author/funder, who has granted medRxiv a license to display the preprint in perpetuity.

It is made available under a CC-BY-NC-ND 4.0 International license .

SUBGROUPING BASED ON CO-OCCURRING PSYCHOPATHOLOGY

Leyfer, O. T., Folstein, S. E., Bacalman, S., Davis, N. O., Dinh, E., Morgan, J., Tager-Flusberg, H., \& Lainhart, J. E. (2006). Comorbid Psychiatric Disorders in Children with Autism: Interview Development and Rates of Disorders. Journal of Autism and Developmental Disorders, 36(7), 849-861.

https://doi.org/10.1007/s10803-006-0123-0

Lindor, E., Sivaratnam, C., May, T., Stefanac, N., Howells, K., \& Rinehart, N. (2019). Problem Behavior in Autism Spectrum Disorder: Considering Core Symptom Severity and Accompanying Sleep Disturbance. Frontiers in Psychiatry, 10, 487. https://doi.org/10.3389/fpsyt.2019.00487

Linzer, D. A., \& Lewis, J. B. (2011). poLCA : An R Package for Polytomous Variable Latent Class Analysis. Journal of Statistical Software, 42(10). https://doi.org/10.18637/jss.v042.i10

Lombardo, M. V., Lai, M.-C., \& Baron-Cohen, S. (2019). Big data approaches to decomposing heterogeneity across the autism spectrum. Molecular Psychiatry, 24(10), 1435-1450. https://doi.org/10.1038/s41380018-0321-0

Lord, C., Elsabbagh, M., Baird, G., \& Veenstra-Vanderweele, J. (2018). Autism spectrum disorder. The Lancet, 392(10146), 508-520. https://doi.org/10.1016/S0140-6736(18)31129-2

Lord, C., Luyster, R., Guthrie, W., \& Pickles, A. (2012). Patterns of developmental trajectories in toddlers with autism spectrum disorder. Journal of Consulting and Clinical Psychology, 80(3), 477-489.

https://doi.org/10.1037/a0027214

Louwerse, A., Eussen, M. L. J. M., Van der Ende, J., de Nijs, P. F. A., Van Gool, A. R., Dekker, L. P., Verheij, C., Verheij, F., Verhulst, F. C., \& Greaves-Lord, K. (2015). ASD Symptom Severity in Adolescence of Individuals Diagnosed with PDD-NOS in Childhood: Stability and the Relation with Psychiatric Comorbidity and Societal Participation. Journal of Autism and Developmental Disorders, 45(12), 3908-3918. https://doi.org/10.1007/s10803-015-2595-2

Mannion, A., \& Leader, G. (2013). An analysis of the predictors of comorbid psychopathology, gastrointestinal symptoms and epilepsy in children and adolescents with autism spectrum disorder. Research in Autism Spectrum Disorders, 7(12), 1663-1671. https://doi.org/10.1016/j.rasd.2013.10.002 Matsushima, N., Miyawaki, D., Tsuji, H., Takahashi, K., Horino, A., Kawaguchi, T., Suzuki, F., \& Kiriike, N. (2008). Evaluation of attention-deficit/hyperactivity disorder symptoms in male children with highfunctioning pervasive developmental disorders. Osaka City Medical Journal, 54(1), 1-10. 
medRxiv preprint doi: https://doi.org/10.1101/2021.07.19.21260784; this version posted December 1, 2021. The copyright holder for this preprint (which was not certified by peer review) is the author/funder, who has granted medRxiv a license to display the preprint in perpetuity. It is made available under a CC-BY-NC-ND 4.0 International license .

Mazefsky, C. A., Schreiber, D. R., Olino, T. M., \& Minshew, N. J. (2014). The association between emotional and behavioral problems and gastrointestinal symptoms among children with high-functioning autism. Autism, 18(5), 493-501. https://doi.org/10.1177/1362361313485164

McBride, N. M., Weinzimmer, S. A., La Buissonnière-Ariza, V., Schneider, S. C., Ehrenreich May, J., Lewin, A. B., McGuire, J. F., Goodman, W. K., Wood, J. J., \& Storch, E. A. (2020). The Impact of Comorbidity on Cognitive-Behavioral Therapy Response in Youth with Anxiety and Autism Spectrum Disorder. Child Psychiatry \& Human Development, 51(4), 625-635. https://doi.org/10.1007/s10578-020-00961-2

Miller, M., Musser, E. D., Young, G. S., Olson, B., Steiner, R. D., \& Nigg, J. T. (2019). Sibling Recurrence Risk and Cross-aggregation of Attention-Deficit/Hyperactivity Disorder and Autism Spectrum Disorder. JAMA Pediatrics, 173(2), 147. https://doi.org/10.1001/jamapediatrics.2018.4076

Mosner, M. G., Kinard, J. L., Shah, J. S., McWeeny, S., Greene, R. K., Lowery, S. C., Mazefsky, C. A., \& Dichter, G. S. (2019a). Rates of Co-occurring Psychiatric Disorders in Autism Spectrum Disorder Using the Mini International Neuropsychiatric Interview. Journal of Autism and Developmental Disorders, 49(9), 3819-3832. https://doi.org/10.1007/s10803-019-04090-1

Mosner, M. G., Kinard, J. L., Shah, J. S., McWeeny, S., Greene, R. K., Lowery, S. C., Mazefsky, C. A., \& Dichter, G. S. (2019b). Rates of Co-occurring Psychiatric Disorders in Autism Spectrum Disorder Using the Mini International Neuropsychiatric Interview. Journal of Autism and Developmental Disorders, 49(9), 3819-3832. https://doi.org/10.1007/s10803-019-04090-1

Mullen, E. M. (1995). Mullen scales of early learning (pp. 58-64). Circle Pines, MN: American Guidance Service Inc.

Murphy, O., Healy, O., \& Leader, G. (2009). Risk factors for challenging behaviors among 157 children with autism spectrum disorder in Ireland. Research in Autism Spectrum Disorders, 3(2), 474-482. https://doi.org/10.1016/j.rasd.2008.09.008

Muskens, J. B., Velders, F. P., \& Staal, W. G. (2017). Medical comorbidities in children and adolescents with autism spectrum disorders and attention deficit hyperactivity disorders: a systematic review. European Child \& Adolescent Psychiatry, 26(9), 1093-1103. https://doi.org/10.1007/s00787-017-1020-0 
medRxiv preprint doi: https://doi.org/10.1101/2021.07.19.21260784; this version posted December 1, 2021. The copyright holder for this preprint (which was not certified by peer review) is the author/funder, who has granted medRxiv a license to display the preprint in perpetuity.

It is made available under a CC-BY-NC-ND 4.0 International license .

SUBGROUPING BASED ON CO-OCCURRING PSYCHOPATHOLOGY

Muskett, A., Capriola-Hall, N. N., Radtke, S. R., Factor, R., \& Scarpa, A. (2019). Repetitive behaviors in Autism Spectrum Disorder: Associations with depression and anxiety symptoms. Research in Autism Spectrum Disorders, 68, 101449. https://doi.org/10.1016/j.rasd.2019.101449

Nicpon, M. F., Doobay, A. F., \& Assouline, S. G. (2010). Parent, teacher, and self perceptions of psychosocial functioning in intellectually gifted children and adolescents with autism spectrum disorder. Journal of Autism and Developmental Disorders, 40(8), 1028-1038.

Nordahl, C. W., losif, A.-M., Young, G. S., Hechtman, A., Heath, B., Lee, J. K., Libero, L., Reinhardt, V. P., Winder-Patel, B., Amaral, D. G., Rogers, S., Solomon, M., \& Ozonoff, S. (2020). High Psychopathology Subgroup in Young Children With Autism: Associations With Biological Sex and Amygdala Volume. Journal of the American Academy of Child \& Adolescent Psychiatry, 59(12), 1353-1363.e2.

https://doi.org/10.1016/j.jaac.2019.11.022

O'Brien, G., \& Pearson, J. (2004). Autism and Learning Disability. Autism, 8(2), 125-140. https://doi.org/10.1177/1362361304042718

Park, S., Cho, S.-C., Cho, I. H., Kim, B.-N., Kim, J.-W., Shin, M.-S., Chung, U.-S., Park, T.-W., Son, J.-W., \& Yoo, H. J. (2012). Sleep problems and their correlates and comorbid psychopathology of children with autism spectrum disorders. Research in Autism Spectrum Disorders, 6(3), 1068-1072.

https://doi.org/10.1016/j.rasd.2012.02.004

Paruthi, S., Brooks, L. J., D’Ambrosio, C., Hall, W. A., Kotagal, S., Lloyd, R. M., Malow, B. A., Maski, K., Nichols, C., Quan, S. F., Rosen, C. L., Troester, M. M., \& Wise, M. S. (2016). Recommended Amount of Sleep for Pediatric Populations: A Consensus Statement of the American Academy of Sleep Medicine. Journal of Clinical Sleep Medicine, 12(06), 785-786. https://doi.org/10.5664/jcsm.5866

Porcu, M., \& Giambona, F. (2017). Introduction to Latent Class Analysis With Applications. The Journal of Early Adolescence, 37(1), 129-158. https://doi.org/10.1177/0272431616648452

Restrepo, B., Angkustsiri, K., Taylor, S. L., Rogers, S. J., Cabral, J., Heath, B., Hechtman, A., Solomon, M., Ashwood, P., Amaral, D. G., \& Nordahl, C. W. (2020). Developmental-behavioral profiles in children with autism spectrum disorder and co-occurring gastrointestinal symptoms. Autism Research, 13(10), 17781789. https://doi.org/10.1002/aur.2354 
medRxiv preprint doi: https://doi.org/10.1101/2021.07.19.21260784; this version posted December 1, 2021. The copyright holder for this preprint (which was not certified by peer review) is the author/funder, who has granted medRxiv a license to display the preprint in perpetuity. It is made available under a CC-BY-NC-ND 4.0 International license .

Richdale, A. L., \& Baglin, C. L. (2015). Self-report and caregiver-report of sleep and psychopathology in children with high-functioning autism spectrum disorder: A pilot study. Developmental Neurorehabilitation, 18(4), 272-279. https://doi.org/10.3109/17518423.2013.829534

Rodriguez-Seijas, C., Gadow, K. D., Rosen, T. E., Kim, H., Lerner, M. D., \& Eaton, N. R. (2020). A transdiagnostic model of psychiatric symptom co-occurrence and autism spectrum disorder. Autism Research, 13(4), 579-590. https://doi.org/10.1002/aur.2228

Ronald, A., Larsson, H., Anckarsäter, H., \& Lichtenstein, P. (2014). Symptoms of autism and ADHD: A Swedish twin study examining their overlap. Journal of Abnormal Psychology, 123(2), 440-451. https://doi.org/10.1037/a0036088

Rosen, T. E., Mazefsky, C. A., Vasa, R. A., \& Lerner, M. D. (2018). Co-occurring psychiatric conditions in autism spectrum disorder. International Review of Psychiatry, 30(1), 40-61.

https://doi.org/10.1080/09540261.2018.1450229

Ruparelia, K., Manji, K., Abubakar, A., \& Newton, C. R. (2017). Investigating the Evidence of Behavioral, Cognitive, and Psychiatric Endophenotypes in Autism: A Systematic Review. Autism Research and Treatment, 2017, 1-17. https://doi.org/10.1155/2017/6346912

Salazar, F., Baird, G., Chandler, S., Tseng, E., O'sullivan, T., Howlin, P., Pickles, A., \& Simonoff, E. (2015). Co-occurring Psychiatric Disorders in Preschool and Elementary School-Aged Children with Autism Spectrum Disorder. Journal of Autism and Developmental Disorders, 45(8), 2283-2294. https://doi.org/10.1007/s10803-015-2361-5

Sikora, D. M., Vora, P., Coury, D. L., \& Rosenberg, D. (2012). Attention-Deficit/Hyperactivity Disorder Symptoms, Adaptive Functioning, and Quality of Life in Children With Autism Spectrum Disorder. Pediatrics, 130(Supplement 2), S91-S97. https://doi.org/10.1542/peds.2012-0900G

Simonoff, E., Jones, C. R. G., Baird, G., Pickles, A., Happé, F., \& Charman, T. (2013). The persistence and stability of psychiatric problems in adolescents with autism spectrum disorders. Journal of Child Psychology and Psychiatry, 54(2), 186-194. https://doi.org/10.1111/j.1469-7610.2012.02606.x

Simonoff, E., Pickles, A., Charman, T., Chandler, S., Loucas, T., \& Baird, G. (2008). Psychiatric Disorders in Children With Autism Spectrum Disorders: Prevalence, Comorbidity, and Associated Factors in a 
medRxiv preprint doi: https://doi.org/10.1101/2021.07.19.21260784; this version posted December 1, 2021. The copyright holder for this preprint (which was not certified by peer review) is the author/funder, who has granted medRxiv a license to display the preprint in perpetuity.

It is made available under a CC-BY-NC-ND 4.0 International license .

SUBGROUPING BASED ON CO-OCCURRING PSYCHOPATHOLOGY

Population-Derived Sample. Journal of the American Academy of Child \& Adolescent Psychiatry, 47(8), 921-929. https://doi.org/10.1097/CHI.0b013e318179964f

Sinzig, J., Bruning, N., Morsch, D., \& Lehmkuhl, G. (2008). Attention profiles in autistic children with and without comorbid hyperactivity and attention problems. Acta Neuropsychiatrica, 20(4), 207-215. https://doi.org/10.1111/j.1601-5215.2008.00292.x

Sinzig, J., Walter, D., \& Doepfner, M. (2009). Attention Deficit/Hyperactivity Disorder in Children and Adolescents With Autism Spectrum Disorder: Symptom or Syndrome? Journal of Attention Disorders, 13(2), 117-126. https://doi.org/10.1177/1087054708326261

Snow, A. V., \& Lecavalier, L. (2011). Comparing Autism, PDD-NOS, and Other Developmental Disabilities on Parent-Reported Behavior Problems: Little Evidence for ASD Subtype Validity. Journal of Autism and Developmental Disorders, 41(3), 302-310. https://doi.org/10.1007/s10803-010-1054-3

Soke, G. N., Maenner, M. J., Christensen, D., Kurzius-Spencer, M., \& Schieve, L. A. (2018). Prevalence of Co-occurring Medical and Behavioral Conditions/Symptoms Among 4- and 8-Year-Old Children with Autism Spectrum Disorder in Selected Areas of the United States in 2010. Journal of Autism and Developmental Disorders, 48(8), 2663-2676. https://doi.org/10.1007/s10803-018-3521-1

Solmi, M., Radua, J., Olivola, M., Croce, E., Soardo, L., Salazar de Pablo, G., II Shin, J., Kirkbride, J. B., Jones, P., Kim, J. H., Kim, J. Y., Carvalho, A. F., Seeman, M. V., Correll, C. U., \& Fusar-Poli, P. (2021). Age at onset of mental disorders worldwide: large-scale meta-analysis of 192 epidemiological studies. Molecular Psychiatry, 1-15. https://doi.org/10.1038/s41380-021-01161-7

Solomon, M., Miller, M., Taylor, S. L., Hinshaw, S. P., \& Carter, C. S. (2012). Autism Symptoms and Internalizing Psychopathology in Girls and Boys with Autism Spectrum Disorders. Journal of Autism and Developmental Disorders, 42(1), 48-59. https://doi.org/10.1007/s10803-011-1215-z

Sprenger, L., Bühler, E., Poustka, L., Bach, C., Heinzel-Gutenbrunner, M., Kamp-Becker, I., \& Bachmann, C. (2013). Impact of ADHD symptoms on autism spectrum disorder symptom severity. Research in Developmental Disabilities, 34(10), 3545-3552. https://doi.org/10.1016/j.ridd.2013.07.028

Strang, J. F., Kenworthy, L., Daniolos, P., Case, L., Wills, M. C., Martin, A., \& Wallace, G. L. (2012). Depression and anxiety symptoms in children and adolescents with autism spectrum disorders without 
medRxiv preprint doi: https://doi.org/10.1101/2021.07.19.21260784; this version posted December 1, 2021. The copyright holder for this preprint (which was not certified by peer review) is the author/funder, who has granted medRxiv a license to display the preprint in perpetuity.

It is made available under a CC-BY-NC-ND 4.0 International license .

SUBGROUPING BASED ON CO-OCCURRING PSYCHOPATHOLOGY

intellectual disability. Research in Autism Spectrum Disorders, 6(1), 406-412.

https://doi.org/10.1016/j.rasd.2011.06.015

Sterling, L., Dawson, G., Estes, A., \& Greenson, J. (2008). Characteristics associated with presence of depressive symptoms in adults with autism spectrum disorder. Journal of Autism and Developmental Disorders, 38(6), 1011-1018.

van Steensel, F. J. A., Bögels, S. M., \& Perrin, S. (2011). Anxiety Disorders in Children and Adolescents with Autistic Spectrum Disorders: A Meta-Analysis. Clinical Child and Family Psychology Review, 14(3), 302-317. https://doi.org/10.1007/s10567-011-0097-0

van Steensel, F. J. A., \& Heeman, E. J. (2017). Anxiety Levels in Children with Autism Spectrum Disorder: A Meta-Analysis. Journal of Child and Family Studies, 26(7), 1753-1767. https://doi.org/10.1007/s10826017-0687-7

Veatch, O. J., Maxwell-Horn, A. C., \& Malow, B. A. (2015). Sleep in Autism Spectrum Disorders. Current Sleep Medicine Reports, 1(2), 131-140. https://doi.org/10.1007/s40675-015-0012-1

Veatch, O. J., Sutcliffe, J. S., Warren, Z. E., Keenan, B. T., Potter, M. H., \& Malow, B. A. (2017). Shorter sleep duration is associated with social impairment and comorbidities in ASD: Sleep duration relates to social impairment. Autism Research, 10(7), 1221-1238. https://doi.org/10.1002/aur.1765

Wang, L. W., Tancredi, D. J., \& Thomas, D. W. (2011). The Prevalence of Gastrointestinal Problems in Children Across the United States With Autism Spectrum Disorders From Families With Multiple Affected Members. Journal of Developmental \& Behavioral Pediatrics, 32(5), 351-360.

https://doi.org/10.1097/DBP.0b013e31821bd06a

Weber, R. J., \& Gadow, K. D. (2017). Relation of Psychiatric Symptoms with Epilepsy, Asthma, and Allergy in Youth with ASD vs. Psychiatry Referrals. Journal of Abnormal Child Psychology, 45(6), 1247-1257. https://doi.org/10.1007/s10802-016-0212-2

White, S. W., Oswald, D., Ollendick, T., \& Scahill, L. (2009). Anxiety in children and adolescents with autism spectrum disorders. Clinical Psychology Review, 29(3), 216-229.

https://doi.org/10.1016/j.cpr.2009.01.003

Wickstrom, J., Dell'Armo, K., Salzman, E., Hooker, J. L., Delehanty, A., Bishop, S., Tassé, M. J., Wetherby, A. M., Piergies, A. M. H., Damiano, D., Rauch, A., \& Thurm, A. (2021). Systematic Review: 
medRxiv preprint doi: https://doi.org/10.1101/2021.07.19.21260784; this version posted December 1, 2021. The copyright holder for this preprint

(which was not certified by peer review) is the author/funder, who has granted medRxiv a license to display the preprint in perpetuity.

It is made available under a CC-BY-NC-ND 4.0 International license .

SUBGROUPING BASED ON CO-OCCURRING PSYCHOPATHOLOGY

Recommendations for Rehabilitation in ASD and ID from Clinical Practice Guidelines [Preprint].

Psychiatry and Clinical Psychology. https://doi.org/10.1101/2021.04.05.21254892

Wiggins, L. D., Tian, L. H., Levy, S. E., Rice, C., Lee, L.-C., Schieve, L., Pandey, J., Daniels, J., Blaskey, L., Hepburn, S., Landa, R., Edmondson-Pretzel, R., \& Thompson, W. (2017). Homogeneous Subgroups of Young Children with Autism Improve Phenotypic Characterization in the Study to Explore Early

Development. Journal of Autism and Developmental Disorders, 47(11), 3634-3645.

https://doi.org/10.1007/s10803-017-3280-4

Wood, J. J., \& Gadow, K. D. (2010). Exploring the nature and function of anxiety in youth with autism spectrum disorders. Clinical Psychology: Science and Practice, 17(4), 281-292.

https://doi.org/10.1111/j.1468-2850.2010.01220.x

Xue Ming, Brimacombe, M., Chaaban, J., Zimmerman-Bier, B., \& Wagner, G. C. (2008). Autism Spectrum

Disorders: Concurrent Clinical Disorders. Journal of Child Neurology, 23(1), 6-13.

https://doi.org/10.1177/0883073807307102

Yoshida, Y., \& Uchiyama, T. (2004). The clinical necessity for assessing Attention Deficit/Hyperactivity

Disorder (AD/HD) symptoms in children with high-functioning Pervasive Developmental Disorder (PDD).

European Child \& Adolescent Psychiatry, 13(5), 307-314. https://doi.org/10.1007/s00787-004-0391-1

Zhang, Z., Abarda, A., Contractor, A. A., Wang, J., \& Dayton, C. M. (2018). Exploring heterogeneity in clinical trials with latent class analysis. Annals of Translational Medicine, 6(7), 119-119.

https://doi.org/10.21037/atm.2018.01.24

Zheng, S., Hume, K. A., Able, H., Bishop, S. L., \& Boyd, B. A. (2020). Exploring Developmental and Behavioral Heterogeneity among Preschoolers with ASD: A Cluster Analysis on Principal Components. Autism Research, 13(5), 796-809. https://doi.org/10.1002/aur.2263 
medRxiv preprint doi: https://doi.org/10.1101/2021.07.19.21260784; this version posted December 1, 2021. The copyright holder for this preprint (which was not certified by peer review) is the author/funder, who has granted medRxiv a license to display the preprint in perpetuity.

It is made available under a CC-BY-NC-ND 4.0 International license.

SUBGROUPING BASED ON CO-OCCURRING PSYCHOPATHOLOGY

\section{Figure 1}

Flowchart illustrating the participant selection process for all analyses.

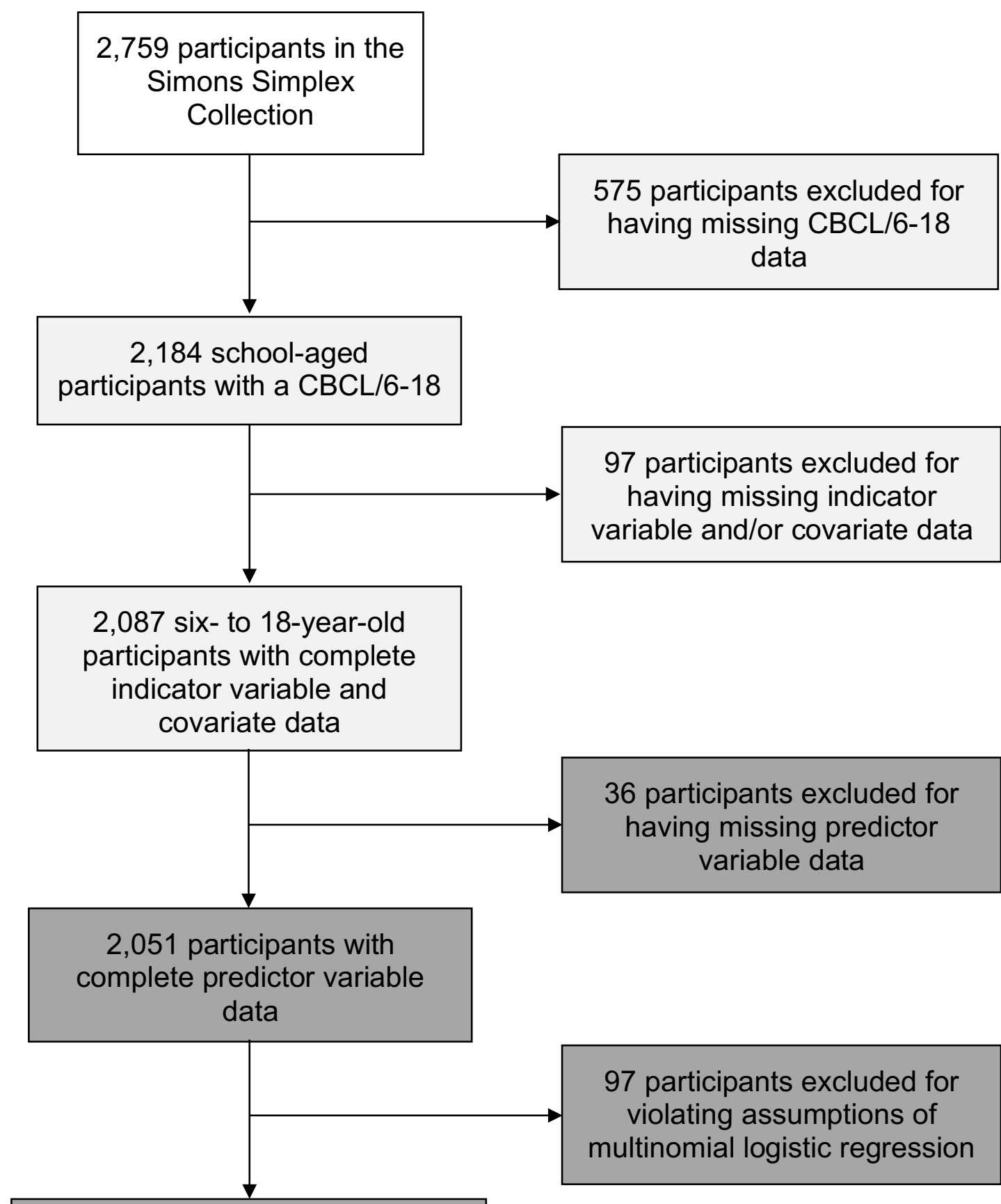

1,954 participants meeting assumptions for multinomial logistic regression 
Table 1

Demographic and clinical characteristics of all four latent classes.

\begin{tabular}{|c|c|c|c|c|c|c|c|c|c|c|}
\hline \multirow[b]{2}{*}{ Sample Descriptives } & \multicolumn{2}{|c|}{ Low Psychopathology } & \multicolumn{2}{|c|}{ Externalizing Problems } & \multicolumn{2}{|c|}{ Internalizing Problems } & \multicolumn{2}{|c|}{ High Psychopathology } & \multicolumn{2}{|c|}{ Total Sample } \\
\hline & $\mathrm{n}$ & $\%$ & $\mathrm{n}$ & $\%$ & $n$ & $\%$ & $\mathrm{n}$ & $\%$ & $\mathrm{n}$ & $\%$ \\
\hline Sample Size & 856 & 41.02 & 258 & 12.36 & 659 & 31.58 & 314 & 15.05 & 2,087 & 100 \\
\hline Sex (males) & 723 & 84.46 & 195 & 75.58 & 611 & 92.72 & 279 & 88.85 & 1,808 & 86.63 \\
\hline Age $^{a}$ (years) & 10.14 & 3.23 & 9.47 & 2.73 & 10.93 & 3.14 & 10.11 & 2.85 & 10.30 & 3.12 \\
\hline $\begin{array}{l}\text { ADOS CSS } \\
\text { NVIQ }^{a}\end{array}$ & $\begin{array}{c}7.49 \\
82.88\end{array}$ & $\begin{array}{c}1.72 \\
26.76\end{array}$ & $\begin{array}{c}7.38 \\
84.53\end{array}$ & $\begin{array}{c}1.69 \\
27.83\end{array}$ & $\begin{array}{c}7.52 \\
87.08\end{array}$ & $\begin{array}{c}1.70 \\
26.17\end{array}$ & $\begin{array}{c}7.36 \\
85.02\end{array}$ & $\begin{array}{c}1.66 \\
25.62\end{array}$ & $\begin{array}{l}7.47 \\
84.73\end{array}$ & $\begin{array}{c}1.70 \\
26.59\end{array}$ \\
\hline \multicolumn{11}{|l|}{ Indicator Variables } \\
\hline $\begin{array}{l}\text { ADHD Problems } \\
\text { Affective Problems }\end{array}$ & $\begin{array}{l}138 \\
52\end{array}$ & $\begin{array}{l}16.12 \\
6.07\end{array}$ & $\begin{array}{l}146 \\
108\end{array}$ & $\begin{array}{l}56.59 \\
41.86\end{array}$ & $\begin{array}{l}267 \\
369\end{array}$ & $\begin{array}{l}40.52 \\
56.00\end{array}$ & $\begin{array}{l}256 \\
280\end{array}$ & $\begin{array}{l}81.53 \\
89.17\end{array}$ & $\begin{array}{l}807 \\
809\end{array}$ & $\begin{array}{l}38.67 \\
38.76\end{array}$ \\
\hline Anxiety Problems & 44 & 5.14 & 22 & 8.53 & 559 & 84.83 & 311 & 99.04 & 936 & 44.85 \\
\hline Conduct Problems & 0 & 0 & 162 & 62.79 & 3 & 0.46 & 241 & 76.75 & 406 & 19.45 \\
\hline \multicolumn{11}{|l|}{$\begin{array}{l}\text { Problems } \\
\text { Predictor Variables }\end{array}$} \\
\hline$N V I Q<70$ & 239 & 27.92 & 68 & 26.36 & 141 & 21.40 & 68 & 21.66 & 516 & 24.72 \\
\hline Sleep Disturbance & 178 & 20.79 & 64 & 24.81 & 166 & 25.19 & 93 & 29.62 & 501 & 24.01 \\
\hline $\begin{array}{l}\text { Allergies/Autoimmune } \\
\text { Disorders }\end{array}$ & 376 & 43.93 & 121 & 46.90 & 332 & 50.38 & 163 & 51.91 & 992 & 47.53 \\
\hline $\begin{array}{l}\text { Gastrointestinal } \\
\text { Disorders }\end{array}$ & 232 & 27.10 & 89 & 34.50 & 227 & 34.45 & 116 & 36.94 & 664 & 31.82 \\
\hline Neurological Disorders & 183 & 21.38 & 72 & 27.91 & 176 & 26.71 & 86 & 27.39 & 517 & 24.77 \\
\hline
\end{tabular}

${ }^{a}$ Age, ADOS CSS, and NVIQ are described using mean and standard deviation rather than number $(\mathrm{n})$ and percent $(\%)$. 


\section{Table 2}

Goodness-of-fit criteria for all six latent class models.

\begin{tabular}{lccccc} 
Model & df & AIC & BIC & Entropy & Smallest Class (\%) \\
\hline 1-class & 26 & $12,904.46$ & $12,932.68$ & 3.09 & NA \\
2-class & 18 & $11,609.27$ & $11,682.64$ & 2.80 & 34.61 \\
3-class & 10 & $11,495.77$ & $11,614.28$ & 2.75 & 25.97 \\
4-class & 2 & $11,440.13$ & $11,603.79$ & 2.74 & 14.55 \\
5-class & -6 & $11,473.61$ & $11,682.42$ & 2.74 & 0 \\
6-class & -14 & $11,611.02$ & $11,864.98$ & 2.77 & 0 \\
\hline
\end{tabular}

Note. Latent class analysis was conducted with five DSM-Oriented Scales of the Child Behavior Checklist for Ages 6 to 18 (Anxiety Problems,

Affective Problems, Attention Deficit/Hyperactivity Problems, Conduct Problems, and Oppositional Defiant Problems) as indicator variables. Age and sex were used as covariates. 


\section{Figure 2}

Percent of participants in each latent class with borderline/clinical symptoms of co-occurring psychopathology.

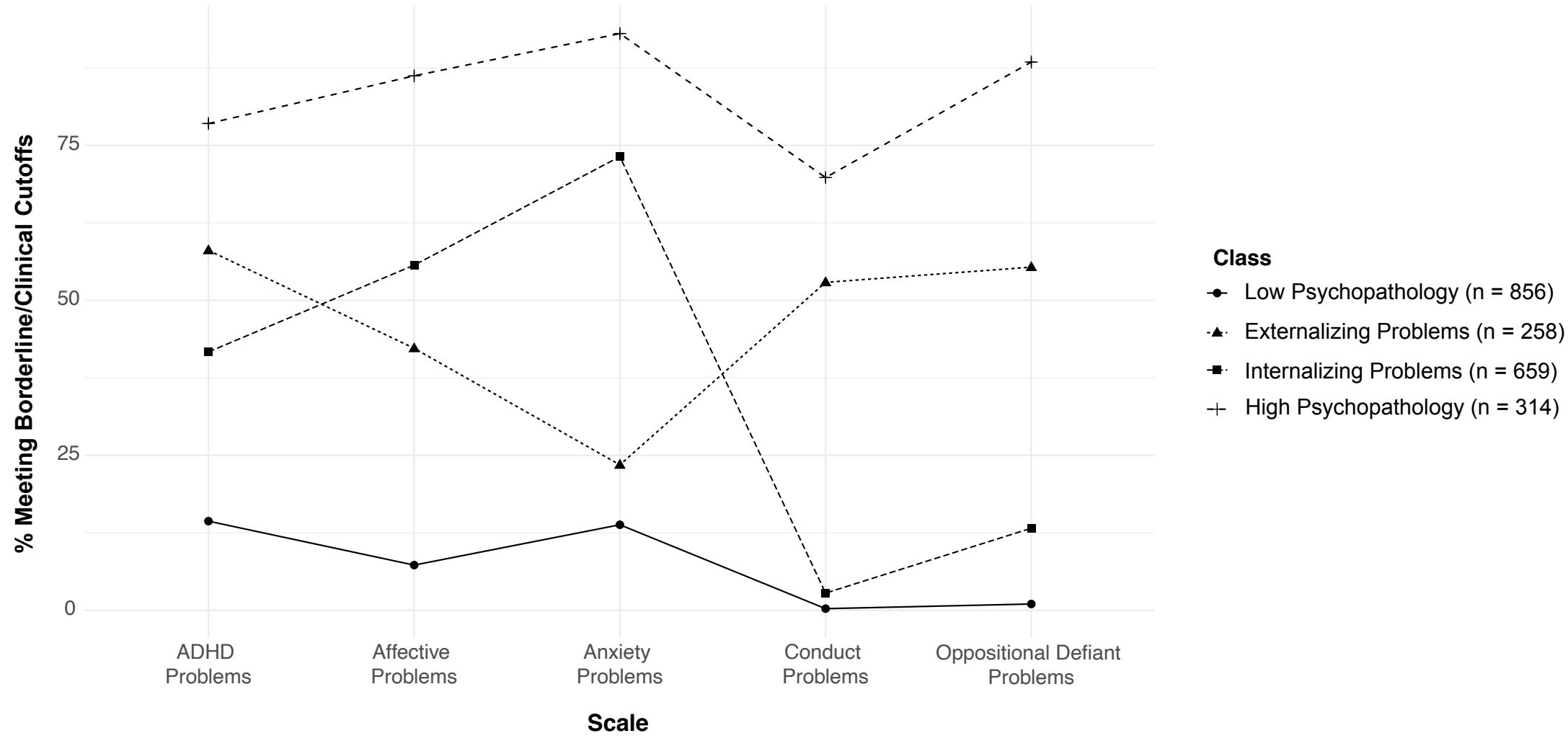

Note. Latent class analysis was conducted with five DSM-Oriented Scales of the Child Behavior Checklist for Ages 6 to 18 (Anxiety Problems, Affective Problems, Attention-Deficit/Hyperactivity Problems, Conduct Problems, and Oppositional Defiant Problems) as indicator variables. Age and sex were used as covariates. 


\section{Table 3}

Odds ratios (OR) and 95\% confidence intervals (95\% Cl) describing the relationship between predictor variables and latent class membership.

\begin{tabular}{|c|c|c|c|c|c|c|}
\hline \multirow[b]{2}{*}{ Predictor Variables } & \multicolumn{2}{|c|}{$\begin{array}{c}\text { Externalizing Problems } \\
(\mathrm{n}=189)\end{array}$} & \multicolumn{2}{|c|}{$\begin{array}{l}\text { Internalizing Problems } \\
(\mathrm{n}=648)\end{array}$} & \multicolumn{2}{|c|}{$\begin{array}{l}\text { High Psychopathology } \\
\qquad(\mathrm{n}=274)\end{array}$} \\
\hline & OR & $95 \% \mathrm{Cl}$ & OR & $95 \% \mathrm{Cl}$ & OR & $95 \% \mathrm{Cl}$ \\
\hline Allergies/Autoimmune Disorders & $1.43^{*}$ & $1.03-1.98$ & $1.27^{*}$ & $1.03-1.57$ & $1.46^{\star *}$ & $1.10-1.93$ \\
\hline Gastrointestinal Disorders & $2.11^{* * *}$ & $1.51-2.94$ & $1.39^{* *}$ & $1.11-1.75$ & $1.90^{* * *}$ & $1.41-2.55$ \\
\hline Sleep Disturbance & $2.07^{* * *}$ & $1.45-2.94$ & $1.37^{*}$ & $1.07-1.75$ & $2.15^{\star \star *}$ & $1.58-2.93$ \\
\hline Neurological Disorders & $2.15^{\star * *}$ & $1.52-3.05$ & $1.39^{* *}$ & $1.09-1.77$ & $1.58^{* *}$ & $1.15-2.17$ \\
\hline NVIQ $<70$ & .72 & $.49-1.05$ & $.63^{\star * *}$ & $.49-.81$ & $.42^{* * *}$ & $.29-.61$ \\
\hline
\end{tabular}

Note. The "Low Psychopathology" subgroup was compared to the "Externalizing Problems," "Internalizing Problems," and "High Psychopathology" subgroups. For each predictor variable, the reference group was "0," meaning that participants did not have a NVIQ $<70$, sleep disturbance, or history of at least one gastrointestinal, neurological, or allergy/autoimmune disorder. ASD symptom severity, measured by ADOS CSS data, was used as a covariate. 97 outliers were excluded for violating the assumptions of multinomial logistic regression.

${ }^{*} \mathrm{p}<.05 .{ }^{* *} \mathrm{p}<.01 .{ }^{* * *} \mathrm{p}<.001$. 